УДК (330+31):614(073):378.4(477-25)КНУ

JEL Classification: A29, 120

Doi: 10.31767/su. 1(88)2020.01.11

\author{
N. V. Kovtun, \\ DSc in Economics, Professor, \\ Head of Department of statistics and demography, \\ Taras Shevchenko National University of Kyiv, \\ E-mail: kovtun_natali@ukr.net \\ ResearcherID: M-6596-2017, \\ ORCID: https://orcid.org/0000-0002-2935-8597; \\ O. I. Kolodyazhna, \\ PhD in Economics, Associate Professor, \\ Covance Clinical Research Ukraine LLC, \\ E-mail: kolodyazhna@gmail.com \\ ORCID: https://orcid.org/0000-0001-6711-2558; \\ K. V. Babin, \\ PhD student, Department of statistics and demography, \\ Taras Shevchenko National University of Kyiv, \\ E-mail: kir.babin.ua@gmail.com \\ ResearcherID: W-4455-2018, \\ ORCID: https://orcid.org/0000-0002-6269-527X
}

\title{
Launch of Master's program (M.Sc.) in Health Economics and Statistics in Taras Shevchenko National University of Kyiv
}

Health Economics has now evolved into a complex science that is based on related disciplines, including epidemiology, statistics, psychology, sociology, operations research, and mathematics. Thus, Health Economics is a set of economic and statistical disciplines that serve as the basis for decision-making by healthcare providers and governments. It also includes a set of analytical methods used in the analysis of the healthcare market.

Health Economics and Statistics is a modern master's program with the main objective to prepare statistics specialists who are able to solve complex problems, make appropriate analytical decisions in the field of clinical research and management decisions in the field of public health that involves conducting research and fostering innovation in the face of uncertainty. Studying statistical methods enables students to acquire up-to-date analytical skills applied to clinical research and healthcare management.

The objectives of the Master's program are focused on providing students with the necessary information about international clinical research experience, forming a critical understanding of the pricing process on the healthcare market, as well as the mechanism for reimbursement of medical expenses in the world. In addition, the program will provide students with an understanding of the organization of existing health systems and methods needed to analyze health policies.

The advantages of the program are tied to the goals of the acquisition of applied statistical analysis skills, which is an indispensable requirement of high qualification of an analyst in clinical research and public health. This is ensured by: 1) integration of practice with academic training; 2) the opportunity to contribute to the development of one's own potential; 3) expanding the capacity for scientific research; 4) the opportunity to defend a master's thesis, working on a real project; 5) providing real career perspectives.

Thus, the implementation of this program will provide an opportunity to prepare highly qualified specialists - analysts in the field of clinical research and public health. Specialists who are in high demand in the private sector (clinical research market) on the national and international level, in the national, regional and local NGOs and institutions in positions related to the planning, collection, processing, and analysis of clinical and public health data, as well as evaluating the quality of managerial decisions in healthcare. All of this, in turn, will help to ensure the competitiveness of specialists and increase the prestige of the specialty.

Key words: health economics, clinical trials, master's program, statistics, analyst specialists.

Background. Ukraine is one of the high morbidity countries in the World with an abundant opportunity for evidence informed disease management protocol development. The statistical department of Covance in Ukraine has come into existence in 2015 with 3 people deployed. Now, the number of employees is

(C) N. V. Kovtun, O. I. Kolodyazhna, K. V. Babin, 2020
13. Among them two employees are having $\mathrm{PhD}$ in statistics and 6 of them are having master's degree. $38.5 \%$ of 13 employees are with the experience in the field for more than 3 years. We conduct a participative (360 degree) and objective evaluation on the work of the statistical department to examine the sustainability of the department for Covance in Ukraine. 
The approach. After working for a reasonably good number of projects we did a survey-based evaluation on the work of the statistical department. Employees engaged in the projects for statistical tasks were participants in this evaluation process and so, the number of participants were 10 out of 13 employees present -5 of them were with the experience in clinical trials for more than 3 years and the remaining, with less than 3 years.
To achieve this goal of evaluation a set of questionnaires was developed and had been sent to all lead statisticians. It included 6 questions capturing the contributions of statistician's support in the project execution during the last period. Lead statisticians assessed the level of statistical support provided using different criteria: performance, complexity, importance, and level of improvement. The questionnaire is presented below.

1. How do you evaluate performance of the statistician in the project delivery using the follow scale?

\begin{tabular}{|c|c|c|c|c|c|}
\hline Scale & $\mathbf{1}$ & $\mathbf{2}$ & $\mathbf{3}$ & $\mathbf{4}$ & $\mathbf{5}$ \\
\hline Level of performance & Poor & Below average & Average & Good & Excellent \\
\hline
\end{tabular}

2. Please support your response against each of the following parameters using the scale of question \#1?

\begin{tabular}{|l|c|c|c|c|c|}
\hline \multicolumn{1}{|c|}{ Parameters } & $\mathbf{1}$ & $\mathbf{2}$ & $\mathbf{3}$ & $\mathbf{4}$ & $\mathbf{5}$ \\
\hline ADaM specs & & & & & \\
\hline ADaM review & & & & & \\
\hline Create QC codes for ADaMs & & & & & \\
\hline TFLs mocks shells & & & & & \\
\hline TFLs annotates & & & & & \\
\hline TFLs review & & & & & \\
\hline Create QC codes for TFLs & & & & & \\
\hline SAP review & & & & & \\
\hline ADDVINT review & & & & & \\
\hline Create QC code for ADDVINT & & & & & \\
\hline
\end{tabular}

Abbreviations in the table: ADaM - Analysis Data Model; QC - Quality Control; SAP - Statistical Analysis Plan; TFLs - Tables Listings Figures; ADDVINT - Analysis Data Interim Deviations.

3. Do you consider that the project execution has enhanced/improved the skills of the statistician?

\begin{tabular}{|l|l|}
\hline Yes & No \\
\hline & \\
\hline
\end{tabular}

4. If "Yes", please, evaluate the level of improvement using the scale below?

\begin{tabular}{|c|c|c|c|c|c|}
\hline Scale & $\mathbf{1}$ & $\mathbf{2}$ & $\mathbf{3}$ & $\mathbf{4}$ & $\mathbf{5}$ \\
\hline $\begin{array}{c}\text { Level of } \\
\text { improvement }\end{array}$ & Reasonable & Expected & Moderate & Above average & Beyond expectation \\
\hline
\end{tabular}

5. How critical is the statistician's support in the project execution?

\begin{tabular}{|c|c|c|c|c|c|}
\hline Scale & $\mathbf{1}$ & $\mathbf{2}$ & $\mathbf{3}$ & $\mathbf{4}$ & $\mathbf{5}$ \\
\hline $\begin{array}{c}\text { Level of } \\
\text { importance }\end{array}$ & Not so important & $\begin{array}{c}\text { Possibly } \\
\text { important }\end{array}$ & $\begin{array}{c}\text { Substitution } \\
\text { possible }\end{array}$ & Critical & $\begin{array}{c}\text { Extremely } \\
\text { important }\end{array}$ \\
\hline
\end{tabular}

6. Please identify the level of complexity of statistical tasks in the project execution?

\begin{tabular}{|c|c|c|c|c|c|}
\hline Scale & $\mathbf{1}$ & $\mathbf{2}$ & $\mathbf{3}$ & $\mathbf{4}$ & $\mathbf{5}$ \\
\hline $\begin{array}{c}\text { Level of } \\
\text { complexity }\end{array}$ & $\begin{array}{c}\text { Simple } \\
\text { tasks }\end{array}$ & $\begin{array}{c}\text { Not so } \\
\text { complex }\end{array}$ & $\begin{array}{c}\text { Standard } \\
\text { tasks }\end{array}$ & $\begin{array}{c}\text { Complex tasks requiring } \\
\text { high level of skills }\end{array}$ & $\begin{array}{c}\text { Highly complex tasks requiring } \\
\text { multidimensional approach }\end{array}$ \\
\hline
\end{tabular}

Survey results. The performance of the statistical tasks in the projects scored overall 4.3 points. But in $50 \%$ of cases the level was good and in $40 \%$ cases, an excellent level (Table 1). In addition, the average score on questions related to (1) the level of improvement of statistical skills, (2) the importance of the statistical support provided and (3) the complexity of statistical tasks was 3.5 points. In $25 \%$ of cases, the level of importance of statistical support was estimated as maximum. 
Table 1

Descriptive statistics for questions \#1, 4-6 of the questionnaire

\begin{tabular}{|c|c|c|c|c|c|c|c|}
\hline 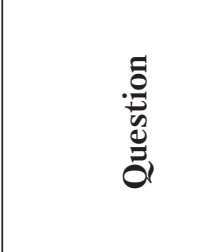 & 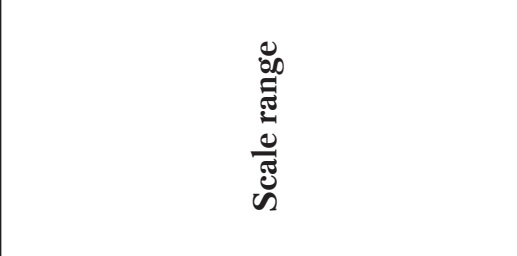 & 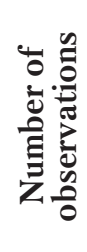 & 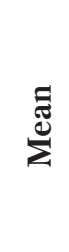 & 苞 & 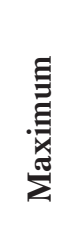 & إّ & 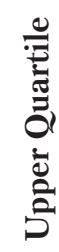 \\
\hline $\begin{array}{l}\begin{array}{l}\text { Level of } \\
\text { performance }\end{array} \\
\end{array}$ & $\begin{array}{l}1-\text { poor } \\
5-\text { excellent }\end{array}$ & 10 & 4.3 & 4.0 & 5.0 & 4.0 & 5.0 \\
\hline $\begin{array}{l}\text { Level of } \\
\text { improvement }\end{array}$ & $\begin{array}{l}1 \text { - reasonable } \\
5 \text { - beyond expectation }\end{array}$ & 8 & 3.5 & 4.0 & 4.0 & 3.0 & 4.0 \\
\hline \begin{tabular}{|l}
$\begin{array}{l}\text { Level of } \\
\text { importance }\end{array}$ \\
\end{tabular} & $\begin{array}{l}1 \text { - not so important } \\
5 \text { - extremely important }\end{array}$ & 10 & 3.5 & 4.0 & 5.0 & 2.0 & 5.0 \\
\hline $\begin{array}{l}\text { Level of } \\
\text { complexity }\end{array}$ & $\begin{array}{l}1 \text { - simple tasks } \\
5 \text { - highly complex tasks requiring } \\
\text { multidimensional approach }\end{array}$ & 10 & 3.5 & 3.5 & 4.0 & 3.0 & 4.0 \\
\hline
\end{tabular}

However, for question: "Do you consider that the project execution has enhanced/improved the skills of the statistician?" $80 \%$ of employees responded for "enhanced/improved the skills of the statistician".

Table 2 presents the level of statistical tasks implementation in projects and that varied between 3 points (average level) and 5 points (excellent level).

Table 2

The distribution of the evaluation of performance of the statistician in the project delivery

\begin{tabular}{|l|c|c|c|c|}
\hline \multicolumn{1}{|c|}{ Level of performance } & Count & Cumulative & Percent & Cumulative percent \\
\hline $3-$ average & 1 & 1 & 10 & 10 \\
\hline $4-$ good & 5 & 6 & 50 & 60 \\
\hline $5-$ excellent & 4 & 10 & 40 & 100 \\
\hline
\end{tabular}

We have also found that $50 \%$ of statisticians showed a good level of statistical tasks implementation in the projects and $40 \%$, achieved an excellent level. So, we can comment that all the statisticians demonstrated good professional capabilities in the projects.
Figures 1 exhibit that in $62.5 \%$ of cases the level of statistical skills improvement was rated "above average" level of performance (score $=4$ ) and for every fourth case, a "moderate" ( score $=3$ ).

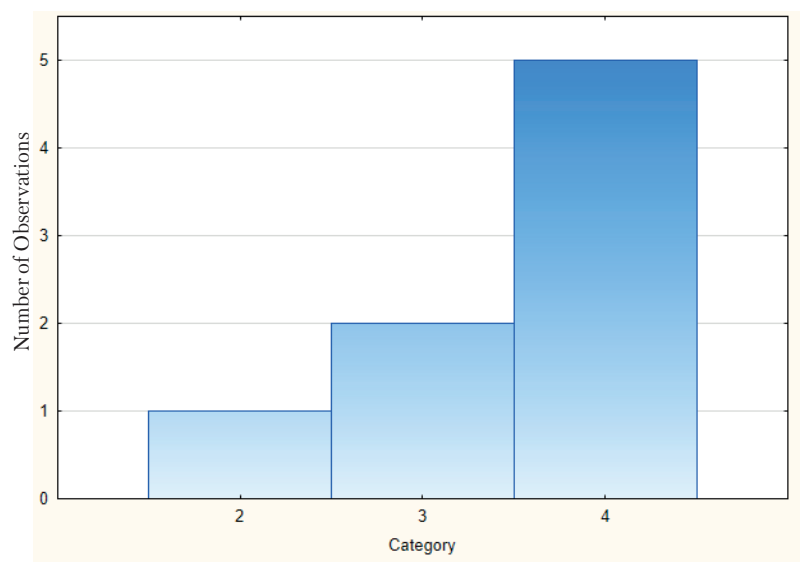

Figure 1. The distribution of the level of improvement

1 - reasonable; 2 - expected; 3 - moderate; 4 - above average; 5 - beyond expectation.

Thus, all the statisticians showed a noticeable improvement of their statistical skills as statistical support in the projects.

The level of statistical support for the projects in $60 \%$ of cases was recognized as "extremely important" and in $30 \%$ of cases, as "important" (Table 3). Albeit, the expert assessed the support as not so important for only 1 case, such an observation could be due to the short-term engagement of working statistician in the project. 
The distribution of the evaluation of importance of the statistician's support in the project execution

\begin{tabular}{|l|c|c|c|c|}
\hline \multicolumn{1}{|c|}{ Level of importance } & Count & Cumulative & Percent & Cumulative \% \\
\hline 1 not so important & 1 & 1 & 10.0 & 10.0 \\
\hline 2 possibly important & 2 & 3 & 20.0 & 30.0 \\
\hline 3 substitution possible & 1 & 4 & 10.0 & 40.0 \\
\hline 4 critical & 3 & 7 & 30.0 & 70.0 \\
\hline 5 extremely important & 3 & 10 & 30.0 & 100.0 \\
\hline
\end{tabular}

Thus, all the statisticians proved to be an essential statistical support during the period of working in the projects.

Figure 2 displays variance in distribution of the evaluation of importance of the statistician's support in the project execution by categories: experience $<3$ years and experience $>3$ years. The distribution shows noticeable difference between employees with experience more than 3 years and less than
3 years. The median score related to employees with experience less than 3 years was evaluated at the level "possibly important" (score $=2$ ) and the median score for employees with experience more than 3 years, "extremely important" (score $=5$ ). Thus, the second group is more homogenous (concentrated around 4 and 5). Hence, experience was a very important for all the statisticians to show good professional capabilities in the projects.

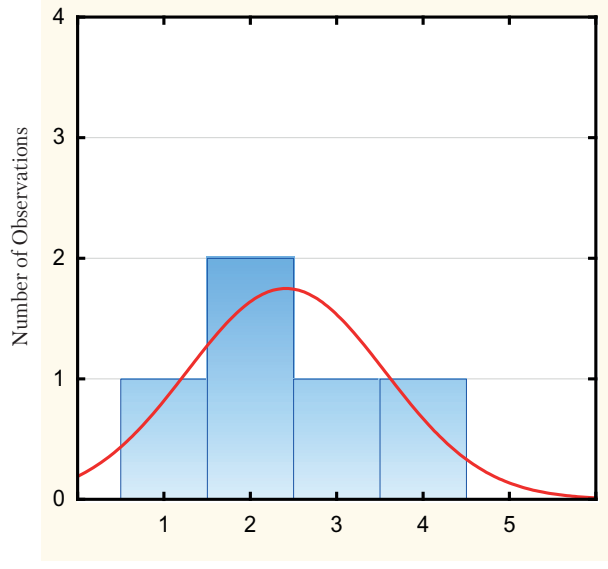

a)

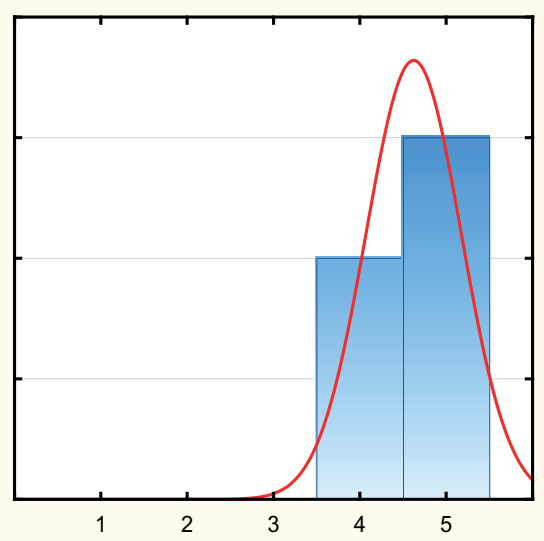

b)

Figure 2. The variance of evaluation of improvement of the statistician in the project delivery be categories a) experience $<3$ years; b) experience $>3$ years.

Considering overall performance level for individual statistical tasks (Table 4), it is worth to note that the average score was 4.1 for 6 (average) tasks, which corresponds to the level as "good" while $75 \%$ of cases scored above 3.7 (above average). Evaluating the level of qualification in general, the minimum assessment level of statistical tasks was 3.6 (above average), and the maximum, 4.6, that corresponds level higher than "good" and "excellent". 75\% of statistical support was performed as "good" and "excellent". The maximum average scores (more than 4 points) were from writing specifications for $\mathrm{ADaMs}$ i.e. 4.6 points, and 4.3 points for reviewing ADaMs and SAPs, as well as creating QC codes for ADaMs. Further, the minimum score for all tasks varied between 3 and 4 points, and that corresponds to the level of "average" and "good".

For the distribution of assessments of individual tasks (Table 4 specifies the number of respondents for each task), we can comprehend that:
- $50 \%$ of statisticians were assessed to the maximum for creating QC codes for ADaMs;

- $\quad 80 \%$ of statisticians were rated between 4 and 5 for creating QC codes for TFLs;

- almost 60\% were rated between 4 and 5 for creating TFLs mocks shells;

- half of the statisticians received grades between 4 and 5 for completing the task of annotating TFLs;

- it is noteworthy that none of the statisticians scored "below average" and "low" marks for these tasks.

The level of complexity of the tasks in the projects was recognized as difficult in $50 \%$ of cases, requiring quite high qualifications. However, on average, the complexity of the statistical tasks performed was estimated by experts at 3.5 points, which is characterized by a level different from standard tasks and is more likely towards complex tasks that require a sufficiently high level of skills in statistical work. Therefore, we can say that the 
Descriptive statistics of the level of performance* by tasks

\begin{tabular}{|c|c|c|c|c|c|c|c|c|c|}
\hline 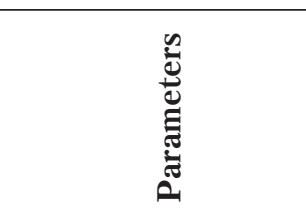 & 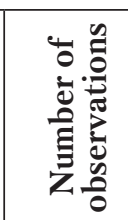 & 胥 & $\frac{\stackrel{0}{\sigma}}{\Sigma}$ & 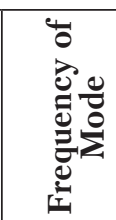 & 䒠 & 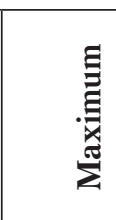 & 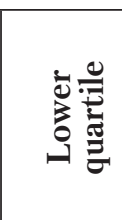 & 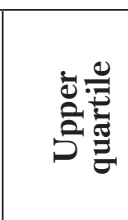 & 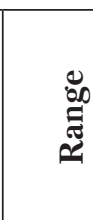 \\
\hline ADaM specs & 7 & 5.0 & 5 & 4 & 4.0 & 5.0 & 4.0 & 5.0 & 1.0 \\
\hline ADaM review & 8 & 4.0 & 4 & 6 & 4.0 & 5.0 & 4.0 & 4.5 & 1.0 \\
\hline $\begin{array}{l}\text { Create QC codes for } \\
\text { ADaMs }\end{array}$ & 6 & 4.5 & 5 & 3 & 3.0 & 5.0 & 4.0 & 5.0 & 2.0 \\
\hline TFLs mocks shells & 7 & 4.0 & 3 & 3 & 3.0 & 5.0 & 3.0 & 5.0 & 2.0 \\
\hline TFLs annotates & 6 & 3.5 & 3 & 3 & 3.0 & 5.0 & 3.0 & 4.0 & 2.0 \\
\hline TFLs review & 7 & 4.0 & 4 & 5 & 3.0 & 5.0 & 4.0 & 4.0 & 2.0 \\
\hline $\begin{array}{l}\text { Create QC codes for } \\
\text { TFLs }\end{array}$ & 6 & 4.0 & 4 & 4 & 3.0 & 5.0 & 4.0 & 4.0 & 2.0 \\
\hline SAP review & 4 & 4.5 & 5 & 2 & 3.0 & 5.0 & 3.5 & 5.0 & 2.0 \\
\hline ADDVINT review & 1 & 4.0 & 4 & 1 & 4.0 & 4.0 & 4.0 & 4.0 & $\mathrm{x}$ \\
\hline $\begin{array}{l}\text { Create QC code for } \\
\text { ADDVINT }\end{array}$ & 1 & 4.0 & 4 & 1 & 4.0 & 4.0 & 4.0 & 4.0 & $\mathrm{x}$ \\
\hline Average by tasks & 6 & 4.0 & 4.0 & $\mathrm{x}$ & 3.3 & 5.0 & 3.7 & 4.5 & $\mathrm{x}$ \\
\hline $\begin{array}{l}\text { Average by statisti- } \\
\text { cians }\end{array}$ & 6 & 4.2 & 4.1 & $\mathrm{x}$ & 3.6 & 4.6 & 3.9 & 4.3 & $\mathrm{x}$ \\
\hline
\end{tabular}

*1 = Poor; 2 = Below average; 3 = Average; 4 = Good; 5 = Excellent.

tasks distribution was in conformation between the level of complexity and the statisticians' work experiences.

Thus to conclude, the important findings from this survey are (1) statistical supports in the projects were recognized as essential; (2) projects provided an opportunity to all the statisticians for improving their respective skills; and (3) the complexity of the implemented statistical tasks was found as rather at a complex level and so, the level of execution of statistical tasks in the projects was estimated at a rather higher level.

The outcome: Master's program "Health Economics and Statistics”. Such a participative (360 degree) and objective evaluation of the work have generated confidence on the potential in the department to carry out the statistical tasks of different levels of complexity, and have established the strength of the department inside and outside $\mathrm{Co}^{-}$ vance.

This evidence laden scenario eventually has incited thoughts to (1) sustain the activities of the statistical department of Covance in Ukraine and (2) maintain competitiveness of Covance in the development of science and society. Thus, the launch of Master's program in Health Economics and Statistics in Taras Shevchenko National University of Kyiv with perpetual support from and collaborative actions with the statistical department of Covance in Ukraine is an effort to translate such thoughts into actions. The Program will start in 2019.

The course structure of Master's program in Health Economics and Statistics (the set of topics with content and their distribution by semester) is presented in Table 5 .

Table 5

The course structure of Master's program in Health Economics and Statistics

\begin{tabular}{|l|l|l|}
\hline \multicolumn{1}{|c|}{$\begin{array}{c}\text { Semester } \\
\text { Credits }\end{array}$} & \multicolumn{1}{|c|}{ Disciplines / Credits } & \multicolumn{1}{c|}{ Content } \\
\hline $\begin{array}{l}\text { I semester / } 31 \\
\text { Credits }\end{array}$ & $\begin{array}{l}\text { Health systems - } \\
5 \text { credits }\end{array}$ & $\begin{array}{l}\text { What is a health system? The typology of health systems. } \\
\text { What are the objectives of the health system and what are the } \\
\text { relationships between efficiency, equity and expenditure control? } \\
\text { What is the role of government in the health systems? } \\
\text { Quasi-markets, competition and market failures. } \\
\text { How should priorities be set? } \\
\text { Performance measurement }\end{array}$ \\
\cline { 2 - 3 } & $\begin{array}{l}\text { Pharmaceutical economics }- \\
6 \text { credits }\end{array}$ & $\begin{array}{l}\text { Market access - authorisation and regulatory approvals. } \\
\text { Pricing and reimbursements. } \\
\text { Outcome analysis }\end{array}$ \\
\cline { 2 - 3 } & $\begin{array}{l}\text { Epidemiology - } \\
6 \text { credits }\end{array}$ & $\begin{array}{l}\text { Fundamentals of epidemiology. } \\
\text { Epidemiology of communicable diseases. } \\
\text { Global epidemiology of non-communicable diseases. } \\
\text { Principle and practice of health promotion }\end{array}$ \\
\hline
\end{tabular}


Table 5, Continuation 1

\begin{tabular}{|c|c|c|}
\hline $\begin{array}{c}\text { Semester / } \\
\text { Credits }\end{array}$ & Disciplines / Credits & Content \\
\hline & $\begin{array}{l}\text { Biostatistics I - } \\
5 \text { credits }\end{array}$ & $\begin{array}{l}\text { Introduction to Biostatistics. } \\
\text { Cohort and case control studies. } \\
\text { Randomised control trials. } \\
\text { Research methodologies and trial designs. } \\
\text { Cluster randomised trials } \\
\end{array}$ \\
\hline & $\begin{array}{l}\text { Introduction to SAS - } 5 \\
\text { credits }\end{array}$ & $\begin{array}{l}\text { Programming language SAS Base: basics. } \\
\text { Work with data, data formats. } \\
\text { Datasets in SAS system. Combine datasets. } \\
\text { Log file: how to read. } \\
\text { SAS Functions. } \\
\text { SAS Options. } \\
\text { SAS Procedures (Part I) } \\
\end{array}$ \\
\hline & $\begin{array}{l}\text { Microeconomics advanced - } \\
4 \text { credits }\end{array}$ & $\begin{array}{l}\text { Market failure: Supplier-induced demand; Adverse selection; } \\
\text { Moral hazards. } \\
\text { Provider payment mechanisms: Prospective vs. retrospective } \\
\text { payments; Social health insurance; Managed care. } \\
\text { Public good: Equity - Efficiency trade-offs; Welfare loss; } \\
\text { Rationing }\end{array}$ \\
\hline \multirow[t]{6}{*}{$\begin{array}{l}\text { II semester/ } 29 \\
\text { Credits }\end{array}$} & $\begin{array}{l}\text { Biostatistics II - } \\
5 \text { credits }\end{array}$ & $\begin{array}{l}\text { Computational biology methods including gene mapping, micro- } \\
\text { array data analysis and other topics in genomics. } \\
\text { Chen-Stein Poisson approximations and EM (Expectation- } \\
\text { Maximisation) algorithms. } \\
\text { Hardy-Weinberg equilibrium, models of selection for populations } \\
\text { of infinite size and population subdivision. } \\
\text { Coalescent theory. } \\
\text { Spatio-temporal statistical models. } \\
\text { Evaluation of trial designs. } \\
\text { Use of qualitative methods. }\end{array}$ \\
\hline & $\begin{array}{l}\text { Data Management - } \\
4 \text { credits }\end{array}$ & $\begin{array}{l}\text { CRF content, structure. } \\
\text { Clinical data composition and properties. } \\
\text { Laboratory data composition and properties. } \\
\text { Rawdata content and structure. } \\
\text { Data cleansing }\end{array}$ \\
\hline & $\begin{array}{l}\text { SAS [Basics] - } \\
5 \text { credits }\end{array}$ & $\begin{array}{l}\text { Array and Loop in SAS. } \\
\text { SAS Procedures (Part II): Proc SQL. Proc Univariate, Proc } \\
\text { Means, Proc Report. } \\
\text { Work in Unix. SAS and Unix interaction. } \\
\text { Good Macros Practice }\end{array}$ \\
\hline & $\begin{array}{l}\text { Health and development - } \\
5 \text { credits }\end{array}$ & $\begin{array}{l}\text { Theories of development. } \\
\text { Concepts of welfare economics - Social choices and } \\
\text { redistribution. } \\
\text { Transitional economies. } \\
\text { Application of the concepts of economics in health system. } \\
\text { Genesis and incorporation of equity in health system }\end{array}$ \\
\hline & $\begin{array}{l}\text { International Standards of } \\
\text { Clinical Research }-5 \text { credits }\end{array}$ & $\begin{array}{l}\text { Good clinical practice (GCP). } \\
\text { International Council for Harmonisation of Technical } \\
\text { Requirements for Pharmaceuticals for Human Use (ICH): } \\
\text { history, structure, process of harmonisation. } \\
\text { Principles of ICH GCP. } \\
\text { Guidelines for: } \\
\text { - institutional review board (IRB) / independent ethics } \\
\text { committee (IEC); } \\
\text { - investigator; } \\
\text { - } \quad \text { trial sponsor (industrial, academic); } \\
\text { - investigator's brochure; } \\
\text { Clinical research associate (CRA) }\end{array}$ \\
\hline & $\begin{array}{l}\text { Research design and method- } \\
\text { ological approach - } 5 \text { credits }\end{array}$ & $\begin{array}{l}\text { Examine the research topics. } \\
\text { Draw up an outline design. } \\
\text { Understand the role of mathematical models. } \\
\text { Description of issues of reliability, validity and responsiveness } \\
\text { of outcome measures, the pros and cons of generic vs. condition- } \\
\text { specific measures, and index versus profile measures. } \\
\text { Familiarisation with the ethical implications of research and the } \\
\text { mechanisms of research governance }\end{array}$ \\
\hline
\end{tabular}


Table 5, Continuation 2

\begin{tabular}{|c|c|c|}
\hline $\begin{array}{c}\text { Semester / } \\
\text { Credits }\end{array}$ & Disciplines / Credits & Content \\
\hline \multirow[t]{9}{*}{$\begin{array}{l}\text { III semester/ } \\
35 \text { Credits }\end{array}$} & $\begin{array}{l}\text { SAS [Advanced] - } \\
5 \text { credits }\end{array}$ & $\begin{array}{l}\text { Output Delivery System. } \\
\text { Proc Template. } \\
\text { SG Procedures. } \\
\text { Good Programming Practice }\end{array}$ \\
\hline & CDISC -5 credits & $\begin{array}{l}\text { Study Data Tabulation Model (SDTM) } \\
\text { Standard for Exchange of Non-clinical Data (SEND) } \\
\text { Analysis Data Model (ADaM) } \\
\text { Operational Data Model (ODM) } \\
\text { Laboratory Data Model (LAB) } \\
\text { Case Report Tabulation Data Definition Specification (CRT- } \\
\text { DDS) } \\
\text { Clinical Data Acquisition Standards Harmonization (CDASH) } \\
\text { CDISC Terminology } \\
\text { DataSet-XML }\end{array}$ \\
\hline & $\begin{array}{l}\text { Economic evaluation of } \\
\text { health policy and health } \\
\text { systems* - } \\
5 \text { credits }\end{array}$ & $\begin{array}{l}\text { What can economics bring to the design of Health Policy? } \\
\text { Quantitative techniques to elicit preferences that are essential } \\
\text { to identify priorities for resource allocation and to measure the } \\
\text { benefits of a policy. } \\
\text { Techniques employed in structural demand estimation. } \\
\text { Measurement of inequities and deprivation. } \\
\text { Impact of government regulation and formulation of policies }\end{array}$ \\
\hline & $\begin{array}{l}\text { Advanced Biostatistics } \\
\text { (focus: Survival Analysis)*- } \\
5 \text { credits }\end{array}$ & $\begin{array}{l}\text { Interpretation of survival analysis data and issues, including } \\
\text { knowledge of life table methodology, competing causes of death, } \\
\text { medical follow-up studies, parametric models and nonparametric } \\
\text { methods. } \\
\text { Advance topics in computational statistics - Splines and Markov } \\
\text { chains. } \\
\text { Current issues in the design and analysis of randomized clinical } \\
\text { trials }\end{array}$ \\
\hline & $\begin{array}{l}\text { SAS Practice in Clinical } \\
\text { Trials* - } \\
5 \text { credits }\end{array}$ & $\begin{array}{l}\text { SAS practice in creating prod and QC SDTMs. } \\
\text { SAS practice in creating prod and QC ADaMs. } \\
\text { SAS practice in creating Listings (self-validation) and produc- } \\
\text { tion and QC Tables. } \\
\text { SAS practice in creating prod and QC Figures. } \\
\text { Good Programming Practice in Clinical Trials }\end{array}$ \\
\hline & $\begin{array}{l}\text { Personnel Management* }{ }^{*} \\
5 \text { credits }\end{array}$ & $\begin{array}{l}\text { Personnel Management - Introduction. } \\
\text { Elements of Personnel Management. } \\
\text { Job Analysis - Job Description and Job Specification. } \\
\text { Performance Appraisal. } \\
\text { Job evaluation. } \\
\text { Personal records. } \\
\text { Employee: relations, stress, performance, discipline, training }\end{array}$ \\
\hline & $\begin{array}{l}\text { Clinical Research and Trials* } \\
-5 \text { credits }\end{array}$ & $\begin{array}{l}\text { Project Management and Research Co-ordination. } \\
\text { Regulatory affairs, Good Clinical Practice and Ethics }\end{array}$ \\
\hline & $\begin{array}{l}\text { Statistics and Econometrics } \\
{[\mathrm{I}]^{*}-} \\
5 \text { credits }\end{array}$ & $\begin{array}{l}\text { Basic statistical methods, including statistical estimation, } \\
\text { hypothesis testing, analysis of variance and longitudinal data. } \\
\text { Concepts of probability. } \\
\text { Correlation. } \\
\text { Linear Regression Analysis. } \\
\text { Multiple Regression Analysis and Data Transformations. } \\
\text { Heteroskedasticity and Autocorrelation. } \\
\text { Dummy Variables. } \\
\text { Microeconometrics: Binary Dependent Variables. } \\
\text { Microeconometrics: Censored Regression Analysis and Sample } \\
\text { Selection }\end{array}$ \\
\hline & $\begin{array}{l}\text { Epidemiology }[\mathrm{II}]^{*}-5 \text { cred- } \\
\text { its }\end{array}$ & $\begin{array}{l}\text { Environmental epidemiology. } \\
\text { Modelling and the dynamics of infectious diseases }\end{array}$ \\
\hline
\end{tabular}


Table 5, Continuation 3

\begin{tabular}{|c|c|c|}
\hline $\begin{array}{l}\text { Semester / } \\
\text { Credits }\end{array}$ & Disciplines / Credits & Content \\
\hline \multirow[t]{8}{*}{$\begin{array}{l}\text { IV semester/ } \\
25 \text { Credits }\end{array}$} & $\begin{array}{l}\text { Valuing health* }{ }^{*}- \\
5 \text { Credits }\end{array}$ & $\begin{array}{l}\text { Instruments to valuing health outcomes. } \\
\text { Approaches used to generate utility and other outcomes data for } \\
\text { use in health technology assessment. } \\
\text { Evaluate critically strengths and weaknesses in the QALY model. } \\
\text { Valuate the role of alternative approaches to the QALY }\end{array}$ \\
\hline & $\begin{array}{l}\text { Medical Statistics and } \\
\text { Evidence Synthesis* }-5 \\
\text { credits }\end{array}$ & $\begin{array}{l}\text { Application of the Bayesian approach to statistical inference. } \\
\text { Synthesis of evidence from multiple clinical trials. } \\
\text { Understanding the methods of elicitation of experts' beliefs in } \\
\text { the absence of empirical evidence }\end{array}$ \\
\hline & $\begin{array}{l}\text { Pharmaceutical economics } \\
{[\mathrm{II}]^{*}-} \\
5 \text { credits }\end{array}$ & $\begin{array}{l}\text { Systematic Reviews and Evidence Synthesis Principles } \\
\text { Economic evaluation. } \\
\text { Cost-effectiveness modelling in Health Technology Assessment }\end{array}$ \\
\hline & $\begin{array}{l}\text { Statistics and Econometrics } \\
{[\mathrm{II}]^{*}-} \\
5 \text { credits }\end{array}$ & $\begin{array}{l}\text { Data organisation. } \\
\text { Panel data. } \\
\text { Interaction effects with continuous and binary outcomes. } \\
\text { Count data models. } \\
\text { Time series models of heteroscedasticity: autoregressive and gen- } \\
\text { eralized autoregressive conditional heteroscedasticity models. } \\
\text { Multivariate time series models: cointegration, error correction } \\
\text { mechanisms, vector autoregressive models - estimation, identifi- } \\
\text { cation and causality. } \\
\text { Matching methods (propensity score matching). } \\
\text { Difference-in-difference methods. } \\
\text { Instrumental variables methods. } \\
\text { Regression discontinuity methods }\end{array}$ \\
\hline & $\begin{array}{l}\text { Professional and Corporate } \\
\text { Ethics* - } \\
5 \text { credits }\end{array}$ & $\begin{array}{l}\text { Institutional Review Board/Independent Ethics Committee } \\
\text { (IRB/IEC): history, description, structure. } \\
\text { Principles of GCP that apply to IRB/IEC. } \\
\text { Adapting IRB review to social science. } \\
\text { Adapting IRB review to big data research. } \\
\text { Managing conflicts of interest }\end{array}$ \\
\hline & $\begin{array}{l}\text { Internship [Practice] - } 6 \\
\text { credits }\end{array}$ & $\begin{array}{l}\text { Working on the project: } \\
\text { Creating CRF and Mock Shells annotations, Creating SDTM; } \\
\text { ADAM; Listing, Tables (safety and efficacy), Figure (safety or } \\
\text { efficacy), Review: SDTM, ADAM, TFLs }\end{array}$ \\
\hline & \multirow[t]{2}{*}{ Evaluations of the course } & $\begin{array}{l}\text { Master's thesis based on the participation in application relevant } \\
\text { project - } 9 \text { credits; }\end{array}$ \\
\hline & & $\begin{array}{l}\text { General exam (Epidemiology, Pharmaceutical economics, } \\
\text { Biostatistics, Health and development) }\end{array}$ \\
\hline
\end{tabular}

\footnotetext{
* Elective course.
}

Abbreviations in the table: SQL (pronounced "ess-que-el”) - Structured Query Language. SQL is used to communicate with a database. According to ANSI (American National Standards Institute), it is the standard language for relational database management systems; GCP Good Clinical Practice; CDISC Clinical Data Interchange Standards Consortium); SDTM Study Data Tabulation Model; CRF Case Report Form; QALY is a measure of the value of health outcomes. It assumes that health is a function of length of life and quality of life, and combines these values into a single index number. To determine QALYs, one multiplies the utility value associated with a given state of health by the years lived in that state.

Master's program is a 2-years program, 120 credits. $12.5 \%$ of credits are from practice and writing of the Master's thesis. The program includes compulsory and elective courses. The ratio between them is 85 credits to 35 credits. 15 credits of 85 (about 18\%) is from Practice and Master's thesis. The relevant proportion between compulsory and elective courses is approximately 70:30. The focus of the program is oriented to special disciplines such as: Clinical Trials (Standards, Regulatory affairs, Good Clinical Practice and Ethics), Health Systems, Biometrics Statistics, SAS programming, Epidemiology, Pharmaceutical economics.

What is 'health economics' and what are program objectives? "Health Economics and Statistics"
- an application driven Master's program. This program aspires (1) to train specialists in statistics capable of solving complex problems involving epidemiology and economics; and (2) to provide insights for analytical decision making in the field of clinical research and for management decisions in public health arena. The program is designed for carrying out research and encourages innovations in conditions of uncertainty. Program objectives are summarised as:

1) to give students information about international experience of designing and executing clinical trials;

2) to teach participants with a critical understanding of the entire process of health technology assessment, pricing and reimbursement worldwide; 
3) to provide an overview of concepts and techniques essential for analysis of health policies and health systems - health systems financing and health inequalities;

4) to equip students with conceptual and practical tools for initiating applied research;

5) to facilitate self-development into professionally organised and interactive individuals by practicing skills of selection, assimilation and communication.

Learning outcomes. After completion of the program, the students will be able to:

- identify therapeutic value propositions, i.e. positions in the pathway where a new technology is likely of generating value;

- critically evaluate the critical elements of trial design and analysis;

- design and plan a clinical trial within international and good practice procedures and guidelines, in the context of commissioning health technologies;

- undertake the evaluation of superiority and bioequivalence;

- demonstrate knowledge and understanding of epidemiological methods, and their application in a range of health-related issues;

- identify the sources of error and bias in epidemiological studies and suggest strategies to deal with them;

- demonstrate skills in handling data and presenting quantitative results;

- manage computerised epidemiological data and carry out appropriate statistical analysis, and interpret results;

- apply advanced epidemiological skills relating to specific fields of interest (e.g. non-communicable / communicable diseases, human genetic epidemiology, advanced statistical skills);

- apply economic reasoning and models to analyse health systems and policies;

- distinguish between a range of differently organised health systems and reimbursement mechanisms;

- differentiate approaches taken to pharmaceutical pricing in different countries.

Practice integration. Internship in Covance: The course participants shall be assigned tasks from the live projects as part of the learning program. Each participant of the program shall have the mentoring support including supervision from Covance throughout the study program. Such internships (two) during the study program are graded (allocated credits) internships having in-house presentation accompanied with project delivery dossier submission for evaluation.

Faculty. Core modules: Covance, and Research and development divisions of Pharmaceutical companies. Such an approach (strategy) is designed for (1) creating an in-built system for continuous knowledge and skill development opportunities for Professionals
/ Scientists of Covance; (2) dynamically updating the program (course) inputs from engagement with Pharmaceutical companies (the partners and stakeholders of Covance); and (3) nurturing system-wide project/ business development process for Covance, and for employability of course participants in a systematic manner.

The desired outcome. The outcome of this industry - academics interfaced human resources development program is focused on acquiring an allencompassing domain specific knowledge and applied statistical analysis and interpretation skills. This is achieved by:

1. Integration of practice with academic learning.

2. Inbuilt opportunity to develop individual potential.

3. Expanding the scope of scientific research.

4. Producing Master's thesis on the real-life project.

5. Developing the capability for an immediate employment that sustains.

Conclusion: an all encompassing achievement. Having a stake in this M.Sc. program shall enable Covance, the University and the Students to continue being the leader of today and to remain relevant with leadership role in the respective specialty for the days to come. This program orchestrates the aspirations of:

- Covance:

- to leverage the opportunity for continuous knowledge and updating skill;

- to contribute to the global effort of developing local cadre integrated with global priorities;

- to act as a conduit for diffusing best practices.

- University:

- to contribute for developing country capacity with global perspectives;

- to widen research network and enhance research capabilities;

- to sustain M.Sc. program as a program that integrates practice with classroom learning.

- Students:

- to acquire advanced analytical skills in clinical research and health system development;

- to carry learning from classroom to real world applications;

- to produce application relevant Master's thesis;

- to improve probabilities of future employability.

The launch of Master's program in Health Economics and Statistics in Taras Shevchenko National University of Kyiv is an actionable excellence meeting the aspirations of three important stakeholders - Academia, Industry and the Society in a synergistic manner. 


\title{
Recommended reading
}

1. Economics \& Health Economics MSc. (2020). wrew.sheffield.ac.uk. Retrieved from https://www. sheffield.ac.uk/economics/masters/courses/msc_economics_health/index/

2. Master of Science in Health Data Science. (2019). wowr.hsph.harvard.edu. Retrieved from https:// www.hsph.harvard.edu/health-data-science/

3. Double Master's Programme in Health Economics and Management. (2019). wwow2.daad.de. Retrieved from https://www2.daad.de/deutschland/studienangebote/international-programmes/en/detail/5448/

4. Healthcare Policy, Innovation and Management. Master's. (2019). wrere.maastrichtuniversity.nl. Retrieved from https://www.maastrichtuniversity.nl/education/master/master-healthcare-policy-innovation-andmanagement/tuition-fees

5. Master's Programme in Public Health with a Specialization in Health Economics. (2020). werere.umu.se. Retrieved from https://www.umu.se/en/education/master/master-programme-in-public-health-with-aspecialization-in-health-economics/

\author{
Н. В. Ковтун, \\ доктор економічних наук, професор, \\ завідувач кафедри статистики та демографії, \\ Київський національний університет імені Тараса Шевченка, \\ E-mail: kovtun_natali@ukr.net \\ ResearcherID: M-6596-2017, \\ ORCID: https://orcid.org/0000-0002-2935-8597; \\ о. I. Колодяжна, \\ кандидат економічних наук, доцент, \\ Covance Clinical Research Ukraine LLC, \\ E-mail: kolodyazhna@gmail.com \\ ORCID: https://orcid.org/0000-0001-6711-2558; \\ К. В. Бабін, \\ аспірант кафедри статистики та демографії, \\ Київський національний університет імені Тараса Шевченка, \\ E-mail: kir.babin.ua@gmail.com \\ ResearcherID: W-4455-2018, \\ ORCID: https://orcid.org/0000-0002-6269-527X
}

\section{Запуск магістерської програми з економіки та статистики охорони здоров'я в Київському національному університеті імені Тараса Шевченка}

Економіка охорони здоров'я зараз перетворилася на комплексну науку, яка спирається на суміжні дисципліни, включаючи епідеміологію, статистику, психологію, соціологію, дослідження операцій та математику. Отже, економіка охорони здоров'я є комплексом економічних і статистичних дисциплін, які виступають базою прийняття рішень особами - постачальниками медичних послуг та урядом щодо системи охорони здоров’я. Вона також охоплює сукупність аналітичних методів, що застосовуються в аналізі ринку медичних послуг.

“Економіка та статистика охорони здоров'я" - сучасна магістерська програма, головним завданням якої є підготовка фахівців зі статистики, здатних розв'язувати складні завдання та вирішувати нетривіальні проблеми, приймати відповідні аналітичні рішення у сфері клінічних досліджень та управлінські рішення у сфері охорони здоров'я суспільства, що передбачає проведення досліджень та впровадження інновацій в умовах невизначеності. Оволодіння статистичними методами дає можливість студентам набути сучасних навичок аналітичної роботи у сфері клінічних досліджень та охорони здоров'я.

Завдання магістерської програми орієнтовані на надання студентам необхідної інформації про міжнародний досвід проведення клінічних досліджень, формування критичного розуміння процесу ціноутворення в галузі охорони здоров'я, а також механізму відшкодування витрат на медичні послуги, який існує у світі. Крім того, за результатами програми у студентів буде сформовано уявлення про існуючи концепції системи охорони здоров’я та методи, необхідні для аналізу політики у цій сфері.

Переваги освітньої програми орієнтовані на набуття навичок та вмінь прикладного статистичного аналізу, що є невід'ємною вимогою високої кваліфікації аналітика у сфері клінічних досліджень та охорони здоров'я. Це забезпечується: 1) інтеграцією практики з академічним навчанням; 2) можливістю зробити внесок у розвиток власного потенціалу; 3) розширенням можливостей проведення наукових досліджень; 4) можливістю захистити магістерську роботу на реальному проекті; 5) наданням реальної можливості майбутньої працездатності. 
Отже, реалізація цієї програми надасть можливість готувати висококваліфікованих фахівців-аналітиків у сфері клінічних досліджень та охорони здоров'я. Спеціалісти матимуть високий попит на ринку праці у приватному секторі клінічних досліджень національного та міжнародного рівня, у національних, регіональних і місцевих громадських організаціях та установах, на посадах, пов'язаних з плануванням, збиранням, опрацюванням та аналізом клінічних даних і даних, що характеризують здоров'я населення, а також оцінюванням якості управлінських рішень у сфері охорони здоров'я. Усе це, своєю чергою, сприятиме забезпеченню конкурентоздатності фахівців і підвищенню престижу спеціальності.

Ключові слова: економіка охорони здоров'я, клінічні дослідження, магістерська програма, статистика, фахівиі-аналітики.

Bibliographic description for quoting:

Kovtun, N. V., Kolodyazhna, O. I., Babin, K. V. (2020). Launch of Master's program (M.Sc.) in Health Economics and Statistics in Taras Shevchenko National University of Kyiv. Statystyka Ukrainy - Statistics of Ukraine, 1, 91-101. Doi: 10.31767/su. 1(88)2020.01.11.

Бібліографічний опис для цитування:

Ковтун Н. В., Колодяжна О. І., Бабін К. В. Запуск магістерської програми з економіки та статистики охорони здоров'я в Київському національному університеті імені Тараса Шевченка (публікується англійською мовою) // Статистика України. 2020. № 1. С. 91-101. Doi: 10.31767/su. 1(88)2020.01.11. 